\title{
Fractal Dimension in Liver Histological Findings of Wistar Rats Experimentally Intoxicated with Venom of Crotalus durissus terrificus
}

\author{
Isabella Keyko Navarro Saneshigue dos Santos', Paulo Felipe Izique Goiozo², Adriana Falco de Brito², \\ Gabriela Haro de Melo', Cristiane de Pauli Pereira' \& Rosa Maria Barilli Nogueira'
}

\begin{abstract}
Background: Accidents caused by venom of Crotalus durissus snakes, popularly known in Brazil as rattlesnake, are second in relation to the occurrence and first place in deaths in humans and animals, mainly due to the great neurotoxic, myotoxic, coagulant, nephrotoxic and hepatotoxic potential of their venom. The effects observed are due to the action of the main poison fractions and among them we can mention crotoxin (representing 50\% of the total poison), crotamine, gyroxine and conxulxin. The present study aimed to analyze the liver of experimentally poisoned Wistar rats with venom of Crotalus durissus terrificus by means of histological and fractal analysis. The hypothesis is that the venom of Crotalus durissus terrificus is can induce hepatic damage at the dose recommended in this study, that its alterations can be quantified by the fractal dimension and that the antiofidic serum botropic crotalic be able to minimize the hepatic lesions induced by the venom.

Materials, Methods \& Results: Ninety rats were distributed into different groups and treated with: control group (GC, $\mathrm{n}$ = 30) $0.9 \%$ sodium chloride solution; venom group $(\mathrm{GV}, \mathrm{n}=30)$ crotalic venom at the dose of $1 \mathrm{mg} / \mathrm{kg} ;(\mathrm{GVS}, \mathrm{n}=30)$ crotalic venom at the dose of $1 \mathrm{mg} / \mathrm{Kg}$ and antiofidic serum $6 \mathrm{~h}$ after the application of the venom at the dose recommended by the manufacturer. Liver samples were collected at $2 \mathrm{~h}$ (M1), $8 \mathrm{~h} \mathrm{(M2)}$ and $24 \mathrm{~h}$ (M3) after venom administration and submitted to histological analysis and fractal dimension (DF) using the ImageJ ${ }^{\circledR}$ software and box-counting method. Procedures for collecting, processing and analyzing samples were standardized. For statistical analyzes, after the normality was verified by the Shapiro-Wilk test and homogeneity by the Bartlett test, the data were submitted to analysis of variance (ANOVA) with Duncan test contrast with a significance level of 5\%. No significant lesions were observed in GC, however necrosis, cytoplasmic and nuclear vacuolization and absence of inflammatory infiltrate were observed in $8 \mathrm{~h}(\mathrm{M} 2)$ and 24 $\mathrm{h}$ (M3) in GV. In addition to the lesions found in the GV, mononuclear inflammatory infiltrate was evident always ( $2 \mathrm{~h}$, $8 \mathrm{~h}$ and $24 \mathrm{~h}$ ) in the GVS. The lesions of necrosis, cytoplasmic and nuclear vacuolization, considered of greater severity were visualized in M3 (24 h) in both GV and GVS. There was an increase in DF for the same changes in GV and GVS over time, but with no difference between them, but with a significant difference compared to CG. In this study, lesions evidenced in the liver were not minimized by the application of antiofidic serum at the recommended dose and during the time of observation of the animals.

Discussion: This study agrees with other authors about the hepatotoxicity of crotalic venom in relation to histological findings and the results indicate an increase in DF for the findings of vacuolization and necrosis, proving to be an efficient method for the quantitative evaluation of morphological changes induced by venom without observer interference. In addition, non-protection of the liver by antiofidic serum was evident. It is concluded that Crotalus durissus terrificus venom causes important hepatotoxic effects in the first $24 \mathrm{~h}$ after experimental intoxication in rats; DF is effective in the quantitative morphological evaluation of liver changes and was characterized mainly by vacuolization and necrosis; the antiofidic serum did not protect the liver from lesions induced by crotalic venom according to the dose of venom and antiofidic serum and time of observation recommended in this study.
\end{abstract}

Keywords: Crotalus durissus, fractal dimension, histology, hepatotoxicity.

DOI: $10.22456 / 1679-9216.91990$ 


\section{INTRODUCTION}

Serpents of the genus Crotalus durissus they inhabit regions of the Federal District, São Paulo, Mato Grosso, Goiás and Southern Region [4,6,23,32].

The venom of Crotalus durissus terrificus, consisting of an organic fraction corresponding to $90 \%$ of dry weight, which contains proteins, hydrolytic enzymes, non-hydrolytic enzymes, proteolytic enzymes, crotalfina [1,31]. The inorganic fraction representing approximately $10 \%$ of the dry weight. [5,23].

Hepatotoxicity has been reported in some studies, however, most of the time the findings are from cases attended after the accident, and few are from histopathological findings in the induction of the accident in experimental form. [2,3,13,14,16, 22].

A new diagnostic tool called fractal analysis has been cited in some studies as a method of quantifying changes in cells such as retina [11], hepatocytes [27], renal and pulmonary vasculature [10,17,34], cardiac studies [12,18,26,33,35] and neoplasms [7].

The fractal analysis allows a more precise comparison on the size of the tissue lesions found in histological slides and the box-couting technique is one of the most used [19,21].

In this context, the objective of the present study aimed to analyze the liver of experimentally poisoned Wistar rats with venom of Crotalus durissus terrificus by means of histological and fractal analysis. The hypothesis is that the venom of Crotalus durissus terrificus can induce hepatic damage at the dose recommended in this study; that hepatic changes can be quantified by the fractal dimension and that the antiofidic serum is able to minimize the hepatic lesions induced during the evaluation period of the study.

\section{MATERIALS AND METHODS}

\section{Animals and experimental groups}

The experimental procedures used throughout the study were approved by the Ethics Committee on the use of animals from the University of origin.

Ninety animals were divided into three groups, being control group $(\mathrm{CG}, \mathrm{n}=30)$, treated with $0.9 \%$ sodium chloride solution; venom group $(\mathrm{GV}, \mathrm{n}=30)$, treated with crotalic venom; venom and serum group (GVS, $n$ $=30$ ), treated with crotalic venom and antiofidic serum.

The animals were evaluated with $2 \mathrm{~h}$, (M1) $8 \mathrm{~h}$ (M2) and $24 \mathrm{~h}$ (M3) after venom administration.
Center for the study of poisons and venomous animals

The venom of Crotalus durissus terrificus snake was provided by the Poisons and Venomous Animals Studies Center- (CEVAP) ${ }^{1}$ of the Paulista State University (UNESP) - Botucatu, SP, Brazil. Poison inoculation was performed in the middle third of the lateral side of the left thigh of the rat, intramuscular (IM), at a dose of $1 \mathrm{mg} / \mathrm{kg}$. Crotalic bothropic serum $^{2}$ was administered intraperitoneally $6 \mathrm{~h}$ after the administration of venom at the dose recommended by the manufacturer to neutralize the amount of venom inoculated. The $0.9 \%$ sodium chloride solution was administered in the control group in the middle third of the lateral side of the left thigh, intramuscularly.

\section{Sampling and histological analysis}

At different times of evaluation, 10 animals from each group were sacrificed with thiopental sodium at $150 \mathrm{mg} / \mathrm{kg}$ dose [20]. Liver samples were collected and conditioned in $10 \%$ buffered formalin, embedded in paraffin, cut into a $4 \mu \mathrm{m}$ thick microtome, stretched on glass slides with a frosted end and subsequently stained with hematoxylin and eosin (HE).

The method of classification analysis of lesions and scores was made from Gerez et al. modified [15]. As shown in Table 1, the microscopic observations of the liver led to the identification of different lesions and severity allowing to establish a lesion score per animal. The minimum score was 0 and the maximum lesion score was 36.

\section{Fractal dimension}

The different tissue sections of the liver of Wistar rats were photographed using the LEICA microscope (model DM750) 3 coupled to a video camera, which sends digital images to a computer equipped with Image Pro-plus ${ }^{4}$. All scanned microscopic images were captured at 800x600 resolution (400x magnification). To analyze the fractal dimension (DF), the stained images in HE (Figure 1A) went through the binarization process, making them black and white (Figure 1B) with the graph result showing the slope of the regression line with the values of the two logs (Figure $1 \mathrm{C})$. The procedures were performed on Image ${ }^{\circledR}$ software from the United States National Institutes of Health (NIH), available free of charge on the Internet (http://rsbweb.nih.gov/ij/). The box-counting method considers two dimensions, allowing the quantification of the distribution of pixels in this space, not consider- 
ing the texture of the image [21]. This influences that two images with the same distribution of the pixels, one binarized and the other in gray levels, will have the same DF, so the DF calculated with the ImageJ® will always be between 0 and 2, not distinguishing different textures [24].

\section{Statistical analysis}

For statistical analyzes, after the normality was verified by the Shapiro-Wilk test and homogeneity by the Bartlett test, the data were submitted to analysis of variance (ANOVA) with Duncan's test contrast with a significance level of $5 \%$.

Table 1. Scores of histological lesions found in the liver of Wistar rats.

\begin{tabular}{lccc}
\hline Tissue & Type of lesions & Severity factor & Maximal scorres \\
\hline & Apoptosis & 6 & \\
Liver & Inflamatory infiltrate & 6 & 36 \\
& Cytoplasmic vacuolization & 6 & \\
& Nuclear vacuolization & 3 & \\
& Megalocytosis & 6 & \\
& Desorganization of hepatic cords & 3 \\
\hline
\end{tabular}

*The score for each lesion was obtained by multiplynig the severity factor with the extension of the lesion. The score of the organ was then obtained by the sun of each score of the lesion. Severity factor (or degree of severity), $1=$ mild lesions, $2=$ moderate lesions, $3=$ severe lesions. The extent of each lesion (intensity or frequency observed) was evaluated and scored as $0=$ no lesion, $1=$ low extension, $2=$ intermediate extension, $3=$ large extension.

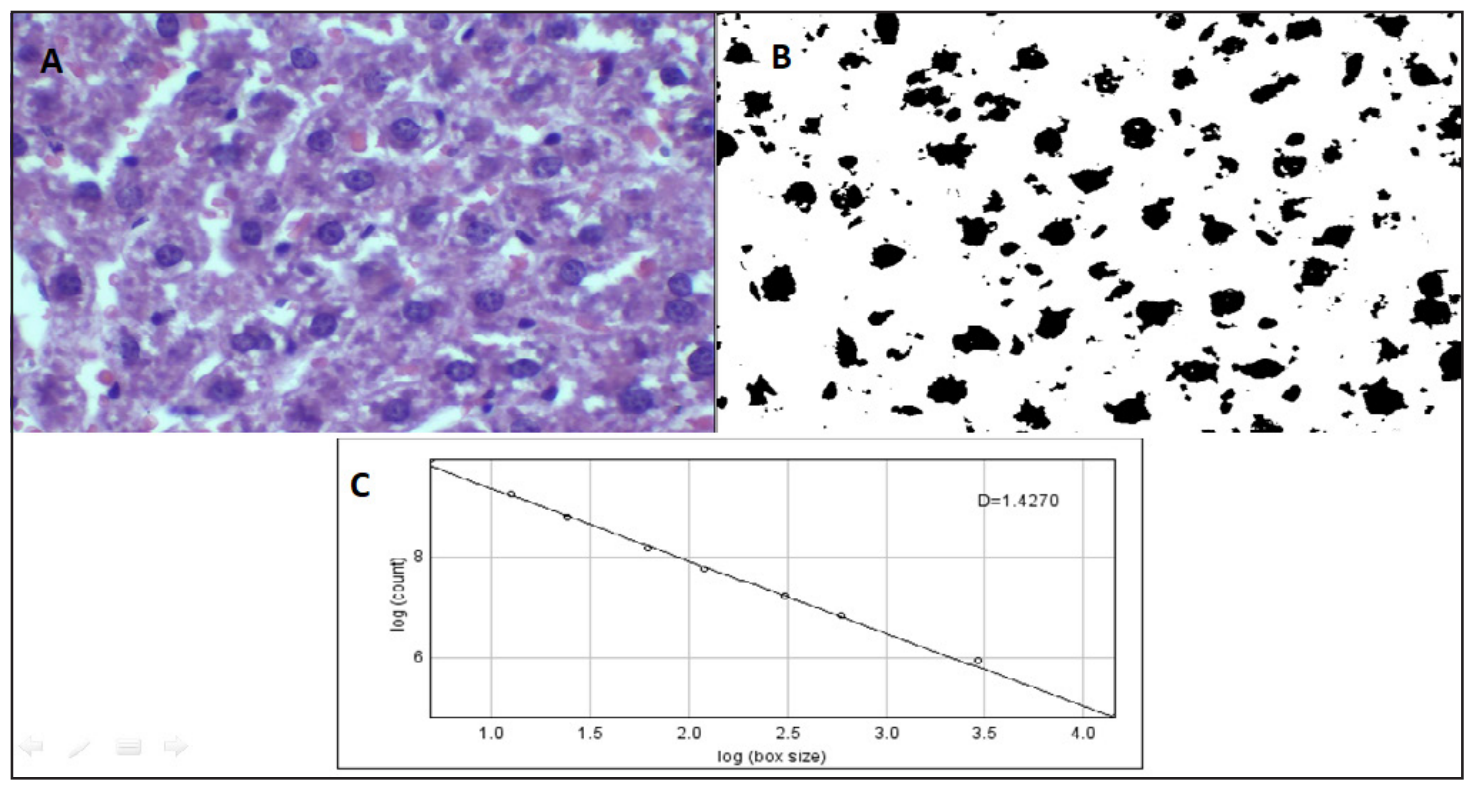

Figure 1. A- Histological section of liver [H\&E; 400x]. B- Image of HE after binarization. C- Linear regression graph showing the slope of the regression line of the values of the two log.

\section{RESULTS}

In the histological analysis, no significant lesions were observed in the GC, however, in all GV and GVS animals, evident and severe lesions were observed and differed $(P<0.05)$ from the GC. Necrosis, cytoplasmic and nuclear vacuolization, mild disruption of hepatocyte cord and absence of inflammatory infiltrate were observed in M2 (Figure 2) and M3 in GV animals. For the GVS animals, the mononuclear inflammatory infiltrate was well evident at all moments, besides necrosis, cytoplasmic and nuclear vacuolization, and cord disruption of hepatocytes being accentuated in M3 (Figure 3). 
The severity of the lesions was proportionally increasing as the evaluation time increased, being significant $(P<0.05)$ in the comparison between $\mathrm{GV}$ and GVS in M1 and M2 (Table 2).

The lesions of greater severity or intensity were visualized in GV and GVS in M3, however, there was no significant statistical difference $(P>0.05)$ between them at this time (Table 2).
Greater values of the fractal dimension for necrosis and cytoplasmic vacuolization were observed in GVS animals, in M2, followed by M3 and M1, while in GV the highest values were observed in M3, M2 and M1 respectively. Statistical differences $(P<0.05)$ were observed in GV and GVS animals in M2 and M3 compared to CG in M1 and M3 (Figure 4).

Table 2. Total lesion score of histology of liver samples.

\begin{tabular}{cccc}
\hline & M1 $(2 \mathrm{~h})$ & M2 $(8 \mathrm{~h})$ & M3 $(24 \mathrm{~h})$ \\
\hline Control group & $5.60 \pm 2.27^{\mathrm{a}}$ & $5.60 \pm 1.26^{\mathrm{a}}$ & $6.22 \pm 2.48^{\mathrm{a}}$ \\
Venom group & $10.22 \pm 2.63^{\mathrm{b}}$ & $12.87 \pm 2.03^{\mathrm{c}}$ & $17.12 \pm 2.64^{\mathrm{ef}}$ \\
Venom/serum group & $16.00 \pm 2.44^{\mathrm{de}}$ & $14.44 \pm 2.06^{\mathrm{cd}}$ & $18.30 \pm 1.76^{\mathrm{f}}$ \\
\hline
\end{tabular}

Different letters in the same column indicate significant statistical differences between groups.

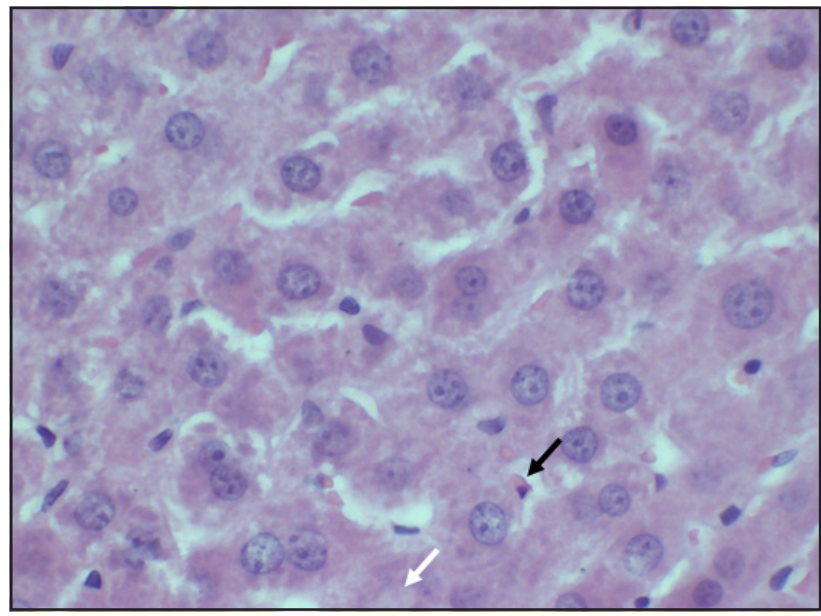

Figure 2. Hepatic photomicrography in venom $(\mathrm{GV}), 8 \mathrm{~h}(\mathrm{M} 2)$ after application of crotalic venom: Discrete disarray of hepatocyte cords, black arrow demonstrates apoptotic body, white arrow cariolysis [H\&E; 400x].

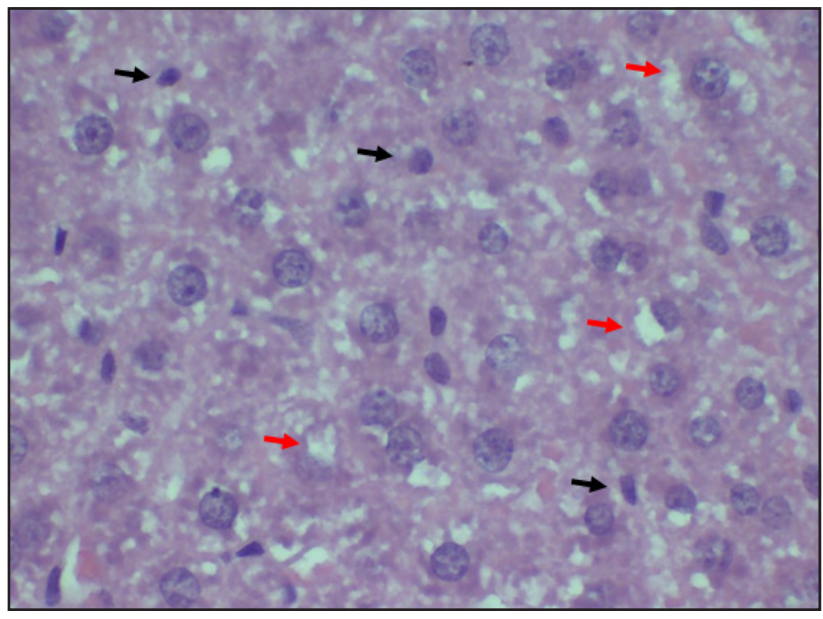

Figure 3. Liver photomicrography in venom/serum group (GVS), 24 h (M3) after application of crotalic venom: Severe hepatocyte cord disarrangement, black arrow demonstrates pyknotic nucleus, red arrow cytoplasmatic vacuolization $[\mathrm{H} \& \mathrm{E} ; 400 \mathrm{x}]$.

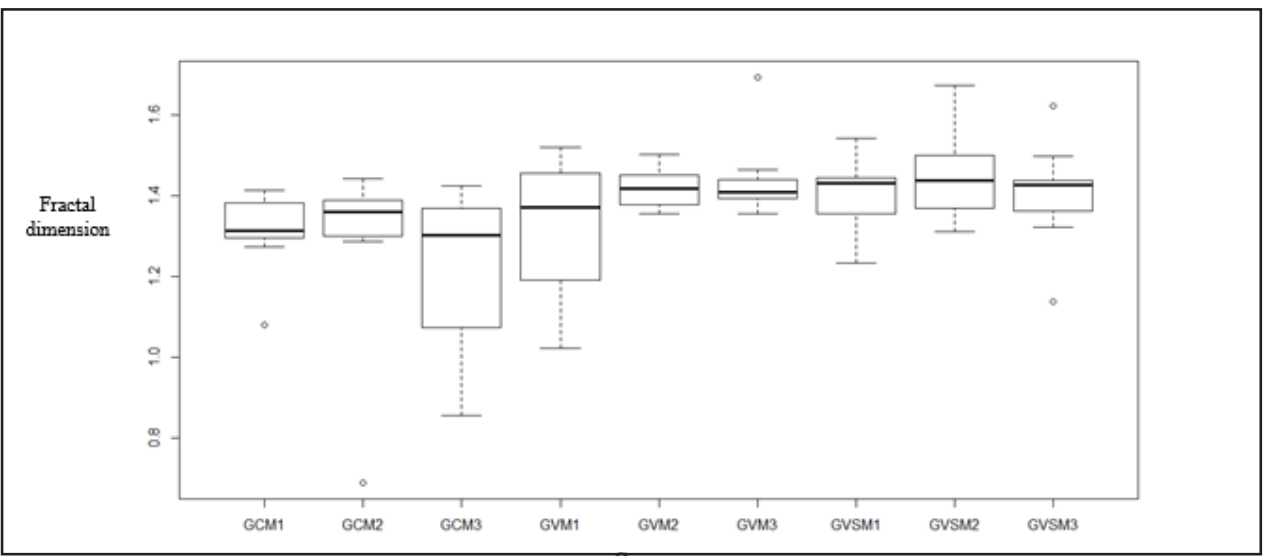

Figure 4. Analysis of the fractal dimension (DF) in the control groups (GC), venom group (GV), venom/serum groups (GVC) at $2 \mathrm{~h}(\mathrm{M} 1), 8 \mathrm{~h}(\mathrm{M} 2)$ and $24 \mathrm{~h}$ venom. 


\section{DISCUSSION}

In this study, the histological changes observed together with the increase in DF values, it is possible to report that the crotalic venom causes an injury of importance and severity in the liver of experimentally intoxicated animals with a dose of $1 \mathrm{mg} / \mathrm{kg}$. Other authors have also reported moderate to severe liver damage in humans [2,3], mouse [13] and dog [30] as a result of the accident caused by the venom of Crotalus durissus.

Liver injury may vary in type, dose and duration of toxin exposure [20]. In hepatocyte reactions to toxic aggression, cellular swelling, steatosis, with or without cholestasis can be observed, and in more severe cases, it may progress to necrosis and hepatic insufficiency. In this way, we can affirm that the dose of $1 \mathrm{mg} / \mathrm{kg}$ of crotalic venom used in this study induced lesions after $2 \mathrm{~h}$ of venom application and progressed over time to more severe and severe lesions such as necrotic cytoplasmic vacuolization and apoptosis .

The crude venom of the Crotalus durissus terrificus snake exerts significant effects on the liver and is related not only to metabolism, but to oxidative stress and mitochondrial functions [9].

The findings of the present study corroborate with another author reporting serious injuries, such as necrosis, which is established two hours after the application of the venom and intensified throughout the evaluation. In addition, the author describes that the antiofidic serum tested alone may contribute to damage to the liver [28].

In this study the fractal dimension was applied for the first time in the analysis of lesions induced by ophidian venom, and no similar study was found in the literature. Its application was performed in the lesion of greater occurrence and severity, that is, vacuolization and necrosis.

In current studies, on the action of venom of ophidians in various tissues and organs histological analysis is performed qualitatively through tissue characteristics, cell morphology, size, nucleus position, presence of inflammatory infiltrate, and other findings [28-30]. However it is known that this type of analysis is dependent on the analyzer, which leads to intra and interobserver variations [21]. Unlike this method, fractal analysis, in addition to quantifying histological changes, is independent of the evaluator, since it is an automatic analysis performed by software [25].

In the fractal dimension when we submitted HE-stained blades to the binarization process, the nuclei are detached from the rest of the cells, so it is possible to measure the size of the infiltrate or other findings by the analysis of its fractal dimension [25]

The findings of this study show that DF is a tool that can be used as a means of quantitative analysis of a lesion, which adds to the study an independent evaluation of the evaluator. Although there were not many significant statistical differences in the comparison between the groups, the fractal dimension analysis showed that animals poisoned by venom and even those submitted to treatment with antiofidic serum showed an increase in the fractal dimension in comparison to CG animals, suggesting that they have a larger fractal dimension. Irregular structures, when analyzed by DF, are quantified with respect to their complexity, thus, higher DF values are related to more complex images [8] and [21]. Although the evaluation of lesions by histology and DF has been efficient, other studies should be carried out in the same or different species for a better understanding of the liver damage caused by crotalic venom, as well as the evaluation of the effects of the antivenom.

\section{CONCLUSIONS}

It is concluded that Crotalus durissus terrificus venom has hepatotoxic effects and fractal dimension is effective in morphological evaluation of the liver and antivenom did not protect the liver from lesions caused by venom.

\section{MANUFACTURERS}

${ }^{1}$ CEVAP-UNESP. Botucatu, SP. Brazil.

${ }^{2}$ Laboratórios Vencofarma do Brasil Ltda. Londrina, PR, Brazil.

${ }^{3}$ Leica Microsystems GmbH. Wetzlar, Germany.

${ }^{4}$ Media Cybernetics. Silver Spring, MD, USA.

Ethical approval. Study approved by the Ethics Committee on the use of animals, protocol no. 3847, of Universidade do Oeste Paulista, Unoeste, Presidente Prudente-SP, Brasil.

Declaration of interest. The authors declare that there is no conflict of interest. Authors alone are responsible for the content and writing of the article. 


\section{REFERENCES}

1 Bancher W., Rosa R.R. \& Furlaneto R.S. 1973. Estudos sobre a fixação eletiva e quantitativa do veneno de Crotalus durissus terrificus nos tecidos nervosos, renal, hepático e muscular de Mus musculus Linnaeus, 1758. Memórias do Instituto Butantan. 37: 139-148.

2 Barraviera B., Bonjorno Júnior J.C., Akaki D., Domingues M.A.C., Pereira P.C.M., Mendes R.P., Machado J.M. \& Meira D.A. 1989. A retrospective study of 40 victims of Crotalus snake bites. Analysis of the hepatic necrosis observed in one patient. Revista da Sociedade Brasileira de Medicina Tropical. 22(1): 5-12.

3 Barraviera B., Coelho K.Y.R., Curi P.R. \& Meira D.A. 1995. Liver dysfunction in patients bitten by Crotalus durissus terrificus (Laurenti, 1768) snakes in Botucatu (state of São Paulo, Brazil). Revista do Instituto de Medicina Tropical de São Paulo. 37(1): 63-69.

4 Blanco B.S. \& Melo M.M. 2014. Acidente Crotálico. Cadernos Técnicos de Medicina Veterinária e Zootecnia - Animais Peçonhentos. 75: 27-35.

5 Beghini D.G. 2001. Isolamento e purificação de uma neurotoxina crotoxina do veneno de Crotalus durissus cascavella: caracterização bioquímica e biológica. 88f. Campinas, SP. Dissertação (Mestrado em Bioquímica) - Programa de Pósgraduação em Bioquímica, Universidade de Campinas-UNICAMP.

6 Brasil 2001. Manual de Diagnóstico e Tratamento de Acidentes por Animais Peçonhentos. 2.ed. Brasília: Fundação Nacional de Saúde, 120p.

7 Chan A. \& Tuszynsky J.A. 2016. Automatic prediction of tumour malignancy in breast cancer with fractal dimension. Royal Society Open Science. 3(12): 1-10.

8 Cross S.S. 1997. Fractals in Pathology. Journal of Pathology. 182(1): 1-8.

9 Da Silva J.G. 2009. Estudo dos efeitos do veneno de Crotalus durissus terrificus sobre o metabolismo e estresse oxidative em figado de ratos. 52f. Curitiba, PR. Dissertação (Mestrado em Farmacologia) - Programa de Pós-graduação em Farmacologia, Universidade Federal do Paraná.

10 Dioguardi N., Grizzi F., Franceschini B., Bossi P. \& Russo C. 2006. Liver fibroses and tissue architectural change measurement using fractal-rectified metrics and Hurst's exponent. World Journal of Gastroenterology. 12(14): 21872194.

11 Doubal F.N., MacgillIvray T.J., Patton N., Dhillon B. Dennis M.S. \& Wardlaw J.M. 2010. Fractal analysis of retinal vessels suggests that a distinct vasculopathy causes lacunar stroke. Neurology. 74(14): 1102-1107.

12 Fabrizii M., Moinfar F., Jelinek H.F., Karperien A. \& Ahammer H. 2014. Fractal Analysis of Cervical Intraepithelial Neoplasia. Plos One. 9(10): 1-9.

13 França R.F. 2004. Estudo histopatológico e bioquímico induzido por veneno de Crotalus durissus terrificus e avaliação hepatoprotetora do diltiazen em fígado de rato Wistar. 99f. São José dos Campos, SP. Dissertação (Mestrado em Ciências Biológicas) - Programa de Pós-graduação em Ciências Biológicas, Universidade do Vale do Paraíba.

14 França F., Vieira R.P., Ferrari E.F., Souza R.A., Osorio R.A.L., Prianti-Jr. A.C.G., Hyslop S., Zamuner S.R., Cogo J.C. \& Ribeiro W. 2009. Acute hepatotoxity of Crotalus durissus terrificus (south american rattlesnake) venon in rats. Journal of Venomous Animals and Toxins Including Tropical Diseases (Online). 15(1): 61-78.

15 Gerez J.R., Pinton P., Callu P., Grosjean F., Oswald I.P. \& Bracarense A.P.F.L. 2015. Deoxynivalenol alone or in combination with nivalenol andzearalenone induce systemic histological changes in pigs. Experimental and Toxicologic Pathology. 67(2): 89-98.

16 Hernández Cruz A., Garcia-Jimenez S., Zucatelli M.R. \& Petricevich V.L. 2008. Pro-and Anti-Inflammatory Cytokines Release in Mice Injected with Crotalus durissus terrificus Venom. Mediators of Inflammation. 1: 1-10.

17 Karslioglu Y., Gunal A., Kurt B., Onguru O. \& Ozcan A. 2009. Fractal dimension of microvasculature in renal oncocytomas and chromophobe renal cell carcinomas. Pathology research and practice. 205(10): 677-681.

18 Keipes M., Ries F. \& Dicato M. 1993. Of the British coastline and the interest of fractals in medicine. Biomedicine \& Pharmacotherapy. 47(9): 409-415.

19 Lee L.H., Tambasco M., Otsuka S., Wright A., Klimowics A., Petrillo S., Morris D., Magliocco A. \& Bebb D.G. 2014. Digital differentiation of non-small cell carcinomas of the lung by the fractal dimension of their epithelial architecture. Micron. 67: 125-131.

20 MacLachlan N.J. \& Cullen J.M. 1998. Fígado, Sistema Biliar e Pâncreas exócrino. In: Carlton W.W. \& McGavin M.D. (Eds). Patologia Veterinária Especial. 2.ed. São Paulo: Artmed, pp.95-131. 
21 Moreira R.D., Moriel A.R., Murta Junior L.O., Neves L.A. \& Godoy M.F. 2011. Fractal dimension in quantifying the degree of myocardial cellular rejection after cardiac transplantation. Revista Brasileira de Cirurgia Cardiovascular. 26(2): 155-163.

22 Da Silva J.G., da Silva S.B., Gris V., Do Rocio A.P.U., Caderia S.M., Eler G.J., Hermoso A.P., Brache U., Dalsenter P.R. \& Acco U. 2011. Effects of the Crotalus durissus terrificus snake venom on hepatic metabolismo and oxidative stress. Journal of Biochemical and Molecular Toxicology. 25(3): 195-203.

23 Nogueira R.M.B. 2011. Intoxicação por animais peçonhentos. In: Nogueira R.M.B. \& Andrade S.F. (Eds). Manual de Toxicologia Veterinária. São Paulo: Roca, pp.295-313.

24 Oliveira M.A.B., Brandi A.C., Santos C.A., Botelho P.H.H., Cortez J.L.L., Godoy M.F. \& Braile D.M. 2014. Comparison of fractal dimension and Shannon entropy in myocytes from rats treated with histidine-tryptophan-glutamate and histidine-tryptophan cetoglutarate. Revista Brasileira de Cirurgia Cardiovascular. 29(2): 156-162.

25 Ozaki G., Camargo R.C.T., Koike T.E., Garcia T.A., Castoldi R.C. \& Camargo Filho J.C.S. 2015. Fractal Analysis of Skeletal Muscle Tissue of Rats Subjected to Stretch Injury. International Journal Morphology. 33(3): 908-913.

26 Pacagnelli F.L., Sabela A.K., Mariano T.B., Ozaki G.A., Castoldi R.C., Carmo E.M., Carvalho R.F., Tomasi L.C., Okashi K. \& Vanderlei L.C. 2016. Fractal dimension in quantifying experimental pulmonar hipertension induced cardiac dysfunction in rats. Arquivo Brasileiro de Cardiologia. 107(1): 33-39.

27 Pantic I., Petrovic D., Paunovic J., Vucevic D., Radosavljevlc T. \& Pantic S. 2016. Age-related reduction of chromatin fractal dimension in toluidine blue -stained hepatocytes. Mechanisms of Ageing and Development. 157: 30-34.

28 Pereira C.P. 2012. Avaliação clínica e da hepatotoxicidade do veneno de Crotalus durissus terrificus e do soro antiofídico em ratos Wistar. 43f. Presidente Prudente - SP. Dissertação (Mestrado em Ciência Animal) - Programa de Pós-graduação em Ciência Animal. Universidade do Oeste Paulista.

29 Sakate M., Nogueira R.M.B. \& Motta Y.P. 2015. Animais peçonhentos. In: Jericó M.M., Andrade Neto J.P. \& Kogika M.M. (Eds). Tratado de Medicina Interna de Cães e Gatos. Rio de Janeiro: Roca, pp.664-677.

30 Sangiorgio F., Sakate M., Nogueira R.M.B. \& Tostes R.A. 2008. Histopathological evaluation in experimental envenomation of dogs with Crotalus durissus terrificus venom. Journal of Venomous Animals and Toxins including Tropical Disease. 14(1): 83-87.

31 Santoro M.L., Sousa e Silva M.C., Gonçalves L.R., Almeida-Santos S.M., Cardoso D.F., Laporta-Ferreira I.L., Saiki M., Peres C.A. \& Sano-Martins I.S. 1999. Comparison of the biological activities in venoms from three subspecies of the South American rattlesnake (Crotalus durissus terrificus, C. durissus cascavella and C. durissus collilineatus). Comparative Biochemistry and Physiology. 122(1): 61-73.

32 Sawaya R.J., Marques O.A.V. \& Martins M. 2008. Composição e História Natural das Serpentes de Cerrado de Itirapina, São Paulo, Sudeste do Brasil. Biota Neotropical. 8(2): 127-149.

33 Šoštarić-Zuckermann I.C., Severin K., Huzak M., Hohsteter M., Kurilj A.G., Artukovic B., Dzaja A. \& Grabarevic Z. 2016. Quantification of morphology of canine circumanal gland tumors: a fractal based study. European Journal of Histochemistry. 60(26): 91-98.

34 Venegas J.G. \& Galletti G.G. 2000. Low-pass filtering, a new method of fractal analysis: application to PET images of pulmonary blood flow. Journal Applied Physiology. 88(4): 1365-1373.

35 Wielgus E., Pawlicki, K., Kawa A., Wloch S. \& Kamuinski M. 2000. Fractal analysis of placenta mature villi in healthy smoking and no smoking women. Medical Science Monitor. 6(2): 271-277. 